AperTO - Archivio Istituzionale Open Access dell'Università di Torino

\title{
Purinergic P2X7 Receptor: A Cation Channel Sensitive to Tumor Microenvironment
}

\section{This is a pre print version of the following article:}

Original Citation:

Availability:

This version is available http://hdl.handle.net/2318/1688776

since 2019-06-05T18:09:20Z

Published version:

DOI:10.2174/1574892814666190116122256

Terms of use:

Open Access

Anyone can freely access the full text of works made available as "Open Access". Works made available under a Creative Commons license can be used according to the terms and conditions of said license. Use of all other works requires consent of the right holder (author or publisher) if not exempted from copyright protection by the applicable law. 


\section{Purinergic P2X7 Receptor: A Cation Channel Sensitive to Tumor Microenvironment}

Giorgia Scarpellino a, Tullio Genova ${ }^{\mathrm{a}, \mathrm{b}}$, Luca Munaron $^{\mathrm{a}^{*}}$ a Department of Life Sciences and Systems Biology, University of Torino, Torino, Italy; ${ }^{\text {b }}$ CIR Dental School, Department of Surgical
Sciences, University of Torino, Torino, Italy giorgia.scarpellino@ unito.it; tullio.genova@,unito.it; luca.munaron@, unito.it

Running title: P2X7 receptor: sensing tumor microenvironment

Received:__ Revised:__Accepted: _

- Background: Purinergic signalling is involved in several physiological and pathophysiological processes. P2X7 receptor (P2X7R) is a calcium-permeable ion channel that is gaining interest as a potential therapeutic target for the treatment of different diseases including inflammation, pain, psychiatric disorders and cancer. P2X7R is ubiquitously expressed and sensitive to high ATP levels, usually found in tumor microenvironment. P2X7R regulates several cell functions, from migration to cell death, but its selective contribution to tumor progression remains controversial.

- Objective: We review the most recent patents focused on the use of P2X7R in the treatment of cancer.

- Results and Conclusion: P2X7R is an intriguing purinergic receptor that plays different roles in tumor progression. Powerful strategies able to selectively interfere with its expression and function should reveal helpful in the development of new anti-cancer therapies.

Keywords: Ion channels, cancer, P2X7, purinergic receptors, purinergic signalling, tumor microenvironment.

\section{INTRODUCTION}

Purinergic signalling involves purine nucleotides and nucleosides such as adenosine 5'-triphosphate (ATP) and adenosine (ADO) [1]. It is involved in short-term neurotransmission, neuromodulation and secretion) and longterm processes (proliferation, differentiation, migration and death in development and regeneration) acting on a variety of fferent cell types [2].

The effects on target cells depend on the binding with purinergic receptors which are classified in two major families: the metabotropic P1 receptors for ADO and the P2 family, including P2Y metabotropic and P2X ionotropic subclasses [3, 4].

P2Y (P2YR) comprise eight subtypes of G protein-coupled receptors (GPCR) activated by adenine and uridine nucleotides (ATP, ADP, UTP and UDP): some of them couple mainly with $\mathrm{G}_{\mathrm{q}}$, activating PLC $\beta$, while others associate preferentially with pertussis toxin-sensitive $G_{i / o}$, suppressing adenylyl cyclase activity [5].

$\mathrm{P} 2 \mathrm{X}$ receptors $(\mathrm{P} 2 \mathrm{XR})$ are ATP-gated calcium-permeable cation channels. Seven subunits (P2X1-7) assemble into homo- or heterotrimeric functional channels, activated upon the binding with three molecules of ATP [6]. Among them, $\mathrm{P} 2 \mathrm{X} 7$ receptor $(\mathrm{P} 2 \mathrm{X} 7 \mathrm{R})$ is gaining growing interest as a potential therapeutic target for the treatment of numerous diseases, including cancer $[6,7]$.

\section{P2X7 RECEPTOR}

$\mathrm{P} 2 \mathrm{X} 7$ receptor $(\mathrm{P} 2 \mathrm{X} 7 \mathrm{R})$ is unique among all the other $\mathrm{P} 2 \mathrm{X}$ isoforms. It differs structurally in the long intracellular carboxy-terminal tail [8], pharmacologically in its low affinity towards ATP $\left(\mathrm{EC}_{50}>100 \mu \mathrm{M}\right)[9]$, but especially for its role as a trigger of inflammatory cytokine release through the large conductance pore, facilitating ions and molecules efflux [10, 11]. Brief recruitment of the channel, when ATP binds the receptor in a range of milliseconds, has long been known to trigger the small cation-selective pore opening. On the other hand, prolonged ATP exposure in a range of seconds results in a larger pore formation, allowing molecules up to $900 \mathrm{Da}$ to flow, and eventually leading to cell death by apoptosis or autophagy [6, 12]. Nowadays, the molecular mechanisms responsible of the large molecules efflux through P2X7R are still not fully elucidated $[13,14]$.

Functional P2X7R is a trimer and its three-dimensional monomer structure could be compared to the shape of a dolphin [15]. The ATP binding site is located at the interface of each pair of monomers, giving rise to the requirement of three molecules of ATP for channel opening. The recent availability of chicken and mammalian P2X7R crystal structures shows that the most largely used antagonists may bind a unique allosteric site, thus allowing the design of improved antagonists by modelling binding sites of the known and presumed inhibitors [13].

Human P2X7R has ten splice variants (P2X7A-J), is highly polymorphic and more than 150 non-synonymous SNPs have been studied [8]. These variants are gaining huge interest in relation to human health and disease $[16,17]$, as demonstrated by the development and publication of many patents. At least eight loss-of-function SNPs have been identified, while for splice variants the scenario is more complex. Among all the 
isoforms, $\mathrm{P} 2 \mathrm{X} 7 \mathrm{~B}$ shares the similar predominant distribution of the canonical full-length P2X7A, even if the receptor made by P2X7B monomer assembly lacks the macropore function but maintains channel activity and stimulates growth [8]. All the isoforms originate from alternative splicing which affects their channel functionality: some non-functional P2X7R $(\mathrm{nfP} 2 \mathrm{X} 7 \mathrm{R})$ are reported in literature and are associated with cancer $[18,19]$. Different isoforms may assembly in order to form heterotrimers with impaired signalling $[19,20]$. A patent from Barden and Gidley-Baird [21] provides antibodies that specifically distinguish between functional and nonfunctional P2X7R, by targeting the characteristic amino acid sequence (200-216) called E200 [19, 22].

Many studies point to a critical role of P2X7R-dependent signalling in a number of physiological and pathological processes, including inflammation, pain, psychiatric disorders, and cancer. Growing evidences highlighted the pivotal role of P2X7R in cancer progression. Consistently, its functionality is strictly dependent on two hallmarks of tumoral microenvironment [23]: acidosis and low $\mathrm{O}_{2}$ [24]. High extracellular proton levels act allosterically on the extracellular histidine 130 (H130) [25]. Conflicting data suggest that hypoxic conditions may modulate P2X7R expression level [26, 27].

\section{P2X7 RECEPTOR AND INFLAMMATION}

$\mathrm{P} 2 \mathrm{X} 7 \mathrm{R}$ is upregulated on immune cells (neutrophils, monocytes, eosinophils, mast cells, macrophages and lymphocytes) during inflammation [10] and can be considered as an immunomodulatory receptor. ATP released from injured cells acts as a "danger signal" by signalling to upregulated P2X7R and increasing immune responses which involve the release of inflammatory cytokines through the larger pore of the channel $[10,28]$. Since a wide range of diseases is associated with P2X7R-mediated inflammation, there has been a growing interest in patent small antagonists of P2X7R as a strategy to counteract various pathological conditions related to inflammation, including cancer [29]. A patent from Hilpert and colleagues [30] discussed the preparation and use of P2X7R antagonists for pharmaceutical use. Many other patents have been developed since 1999 when Astra Zeneca firstly reported the possible therapeutic application of P2X7R inhibitors to treat inflammation and other diseases [31]. Interestingly, the role of P2X7R antagonists in rheumatoid arthritis (RA) is controversial. Three compounds have been tested in clinical trials: Evotec's EVT-401, AstraZeneca's AZD-9056 and Pfizer's CE-224535. The last two didn't show any significant efficacy in RA treatment and for this reason P2X7R doesn't appear to be a functional target in RA [9]. Despite the clinical failure of these two compounds in phase II, P2X7R antagonists are still promising and other human clinical trials have been launched in order to investigate their therapeutic potential in Crohn's and chronic obstructive pulmonary diseases [6]. Importantly, high levels of P2X7R have been found in neuronal degeneration (e.g. Alzheimer's disease [32]), neuropatic pain [33] and in some cancers. A method for preventing and/or treating inflammatory diseases and other disorders associated with $\mathrm{P} 2 \mathrm{X} 7$ upregulation involves the use of RNAi technology [34].

Tumor microenvironment includes different immune cells, including monocytes, macrophages, dendritic cells, lymphocytes and myeloid-derived suppressor cells, that enable tumor growth and progression by directly interacting with cancer cells. This highly inflammatory milieu modulates the immune response against tumors and the signalling through P2X7R on dendritic cells is crucial for the activation of NLRP3 inflammasome [35], which is the most versatile and clinically implicated inflammasome [36]. The subsequent release of IL-1 $\beta$ leads to the stimulation of $\mathrm{CD}^{+}$and $\mathrm{CD} 8^{+}$ lymphocytes $\mathrm{T}$ which mediate the anti-tumor responses. A recent patent discussed a method for treating cancer by polymyxin B administration in combination with ATP as a novel tool to target $\mathrm{T}$ regulating (Treg) $\mathrm{CD}^{+} \mathrm{CD}^{+} 5^{+}$ lymphocytes, preventing excessive immune reactions and are known as T cells suppressors [37]. In particular, the role of ATP in this patent is to stimulate P2X7R on Treg in order to promote apoptosis.

\section{P2X7 RECEPTOR AND CANCER}

As mentioned above, there is a tight connection between P2X7R and cancer, as suggested by multiple lines of evidence. Firstly, inflammatory pathways concur to the pathogenesis of oncogenic disorders. Moreover, the tumor microenvironment is characterized by accumulation of ATP up to the millimolar range, which can be directly released by cancer cells, promoting their migration and metastatisation [6], or indirectly through cell death caused by as hypoxia, inflammation, mechanical stress and non-targeted therapies [19].

Tumor microenvironment is composed of cancer and stromal cells, such as cancer-associated fibroblasts, immune and endothelial cells, even if its composition may change depending on tumor type [38]. The interaction between cancer cells and the surrounding medium is crucial in determining the fate of the tumor, its ability to growth and metastasize [39], especially linked to the effectiveness of host anti-tumor immune response [38].

In order to support tumor growth and its invasive and metastatic potential, cancer cells promote tumor neovascularization supported by endothelial and endothelial progenitor cells (respectively EC and EPC). Interesting, several $\mathrm{Ca}^{2+}$-permeable ion channels play a role in the sustainment of tumor-neoangiogenesis and $\mathrm{P} 2 \mathrm{X} 7 \mathrm{R}$ is among them [40-42]. Consistently, in vitro experimental evidences show the modulation of the main molecular players involved in $\mathrm{Ca}^{2+}$ signalling in both tumor endothelial cells (TEC) and tumor endothelial progenitor cells (TEPC) [40, 43-48]. Even though $\mathrm{Ca}^{2+}$ machinery is far from being used as a target for the anti-cancer therapies [40, 49], the remodelling of $\mathrm{Ca}^{2+}$ signals in TEC could contribute to the resistance of some tumors to standard anti-angiogenic treatments, such as antiVEGF therapies [43, 50, 51]. Another possible explanation for the resistance to anti-VEGF therapy is the ability of EPCs to reach tumor microenvironment and concur to 
neovascularization $[52,53]$. This recruitment is called "homing" and it is induced by several chemokines, among which SDF-1 $\alpha$ plays a pivotal role [54]. It has been shown that the activation of P2X7R on EPCs promotes their homing to gliomas in vivo, thus highlighting a possible therapeutic strategy to overcome the their anti-angiogenic resistance [52]. Other pro-angiogenic roles for $\mathrm{P} 2 \mathrm{X} 7 \mathrm{R}$ are reported in literature: its activation on cancer cells was associated with increased HIF-1 $\alpha$ activity [55], vascular endothelial growth factor (VEGF) $[56,57]$ and matrix metalloproteinases (MMP) production, such as MMP-2 and MMP-9 [58], therefore promoting not only tumor growth and angiogenesis [59] but also invasiveness and metastasis spreading [35, 58, 60]. For these reasons P2X7R blockers could be considered as antiangiogenic molecules and is not surprising that growth and neoangiogenesis of P2X7R-expressing tumors are inhibited not only by Avastin, an anti-VEGF antibody, but also by pharmacological P2X7R blockade and P2X7R silencing in vivo [56].

$\mathrm{P} 2 \mathrm{X} 7 \mathrm{R}$ is over-expressed in cancer cells from many malignant human tumors including leukaemia [61], neuroblastoma [57, 62], mesothelioma [63], esophageal squamous cell carcinoma [64], pancreatic ductal adenocarcinoma [65], breast [66] and skin [67] cancer. This is not surprising, considering its capability to enhance survival and growth in the absence of serum [68], and make it a good tumoral biomarker. In addition, a patent is based on the use of a P2X7R splicing variant as a biomarker for rhabdomyosarcoma, the most frequent soft tissue sarcoma in childhood [69]. Although the involvement of P2X7R in cancer is well established, its actual role is still debated. Intriguingly, P2X7R activation on cancer cells exerts opposite effects, being pro-tumoral is some conditions and anti-tumoral in others [35]. Basal activation of P2X7R contributes to tumor progression by increasing oxidative phosphorylation and aerobic glycolysis, and leading to the increase of intracellular ATP content [55]. In this scenario, tumor cells gain a proliferative advantage through the activation of several intracellular pathways such as NFACTc1, ERK, PI3K/Akt and HIF-1 $\alpha$ [70]. Consistently, many pharmaceutical drugs that act as P2X7R blockers have been used in pre-clinical animal models: they include oATP for colon cancer [56], BBG for ovarian cancer [71], AZ10606120 for pancreatic ductal adenocarcinoma [65] and A740003 for neuroblastoma [57]. There is a growing interest in developing new compounds or antibodies with similar effects. For instance Barden and Gigley-Baird presented a novel method for detection and treatment of cancer by the use of antibodies that bind P2X7R [72, 73]. In particular, these findings relate to a novel epitope on $\mathrm{nfP} 2 \mathrm{X} 7 \mathrm{R}$ that has been used for the generation of the antibodies [74]. The expression of $\mathrm{nfP} 2 \mathrm{X} 7 \mathrm{R}$ in cancer cells is more associated to a pro-tumoral effect than canonical P2X7R, due to its inability to form functional pores and to induce cell death [19]. Other promising patents focused on nfP2X7R have been published, some of which aimed to the production of antibodies to form an immune complex with nfP2X7R: this strategy may provide a method for determining whether a cell, a tissue or extra cellular fluid includes nfP2X7R [21, 75]. Despite the promising results in the aforementioned pre-clinical models, novel therapies based on P2X7R-targeted strategy are feasible only when the receptor is overexpressed. Tumors with low P2X7R expression levels seem only slightly responsive [35]. As mentioned above, not only pro-tumoral effects are associated to $\mathrm{P} 2 \mathrm{X} 7 \mathrm{R}$. Recent in vitro evidences pointed out a possible anti-angiogenic role of P2X7R on TEC [76]. The anti-cancer effect of $\mathrm{P} 2 \mathrm{X} 7 \mathrm{R}$ could be hampered in vivo by the conditions usually found in some solid tumors, as acidosis and hypoxia, which counteract P2X7R functionality. Moreover, the high ATP levels, which are typically found in tumor stroma, overstimulate $\mathrm{P} 2 \mathrm{X} 7 \mathrm{R}$ in order to induce tumor cell death by inducing pro-apoptotic pores. This was demonstrated in many types of cancer but although the outcomes are exciting, clinical trials failed to confirm any anti-cancer effect for extracellular ATP stimulation. A possible explanation could be the expression of $n f P 2 X 7 R$ together with the onset of a resistance towards high ATP concentrations [35]. Through these mechanisms, cancer cells may become able to fulfil P2X7R-dependent functional responses but avoiding lethal consequences [77]. Moreover, a recent study carried out by Young et al suggests a further mechanism to evade ATPinduced cytotoxicity, which involves MMP-2-dependent cleavage of P2X7R [78]. Despite further investigation is needed, strategies aimed at enhancing the potential P2X7Rdependent anti-cancer effect of ATP could be an alternative approach to avoid cancer cell death escape [35]. Consistently, a patent from Gorodeski and $\mathrm{Fu}$ provides a method for inducing apoptosis in premalignant and cancerous cells by administering BzATP, a P2X7 agonist [79]. In particular, this method targets a specific mechanism of apoptosis in cancer cells, which does not involve inflammatory changes, abnormal skin or systemic effects in models of skin carcinogenesis. BzATP reduced papilloma skin formation and triggered the involution of already developed papillomas. Another interesting patent develops a method for the treatment of primary cancer and bone metastasis, based on P2R agonists and P1R antagonists [80]. In the field of oncogenic neurological disorders, many studies reported the involvement of calcium channels in malignant brain tumor progression [81-84]. Importantly, P2X7R regulates proliferation and migration of human glioma cancer cells, and its expression increases with the grade of the tumor [60]. Since 2008, several pharmaceutical companies have patented many CNS available compounds. The principal issue in CNS disorders is to identify molecules able to permeate the bloodbrain barrier (BBB) [85]. For instance, Glaxo Smith Kline's GSK-1482160 is a potent BBB penetrant P2X7R antagonist, which completed phase I clinical trial in human volunteers and was shown to have a role in reducing inflammatory pain. Thanks to its ability to target P2X7R and to be radiolabelled with ${ }^{11} \mathrm{C}$, GSK-1482160 could be useful as a biomarker for neuroinflammation via PET [86]. Inflammatory pathways, activated by increased levels of extracellular adenine nucleotides in the microenvironment and the subsequent purinergic receptors activation, are involved in a number of neuro pathological conditions $[87,88]$ such as neurodegenerative, neuropsychiatric, neuropathic pain and cancer [89]. Neuroinflammation is the major component in neurodegenerative disease [90] and purinergic receptors could 
be valuable targets in the treatment of these pathologies. Particularly, P2X7R antagonists are promising agents for the treatment [28] of Alzheimer's Disease [32], Parkinson's Disease [91], multiple sclerosis [92], amyotrophic lateral sclerosis [93] and also epilepsy [94]. Many molecules have been patented for the treatment of these neurodegenerative diseases [95-98]. Even if these approaches are not directly designed for cancer treatment, they could be helpful to counteract neuroinflammation associated with oncogenic neurological disorders. Interestingly, many P2X7R modulators have been patented as methods to treat affective and mood disorders for the treatment of depression, bipolar disorder, anxiety and sleep disorders [95, 97, 99, 100] and, nonetheless, some of them refer also at their possible application in the treatment of cancer [95, 97].

\section{CONCLUSION}

$\mathrm{P} 2 \mathrm{X} 7 \mathrm{R}$ is a purinergic receptor involved in inflammation and cancer progression. Its activation can produce both proand anti-tumoral effects, depending on the cell type as well as on a variety of different factors. It is considered a key mediator of anti-tumoral immune response [101], but its expression on cancer cell membranes seems to mediate a dual role (Fig. 1). In some conditions, P2X7R triggers programmed cell death [102]: however, at least three factors contribute to counteract this activity: the preferential expression of a nfP2X7R [19], its cleavage by MMP-2 [78] and the influence of tumor microenvironment [77]. On the other hand, P2X7R is known to be a pro-tumor protein promoting tumor growth, angiogenesis, invasiveness and metastasis spreading $[55,56,58]$. In the present work we reviewed some of the most recent patents (Table 1) that involve P2X7R use in the treatment of cancer. Due to the aforementioned opposite biological effects associated to this intriguing purinergic receptor, some patents provide methods based on its recruitment, while other are focused on the development and use of antagonists and/or antibodies aimed to interfere with its activity.

\section{CURRENT \& FUTURE DEVELOPMENTS}

Future efforts should be devoted to overcome the current conflicting mechanistic models proposed for a role of $P 2 X 7 R$ in tumor progression: a helpful contribution will hopefully be provided by the development of new and powerful drugs or molecular strategies to selectively interfere with the large number of $P 2 X 7 R$ splicing variants and polymorphisms.

Another interesting issue would be to design novel therapies focused on the use of non-functional forms of $P 2 X 7 R$ as preferential oncological targets, especially because strong evidence suggests its high expression in different cancer cells and its absence in healthy tissues. In particular, the clear definition of the differential biological roles for 'canonical' ion channel ability and pro-apoptotic pore formation will shed light on the still elusive dual nature of $P 2 X 7 R[18,19]$.

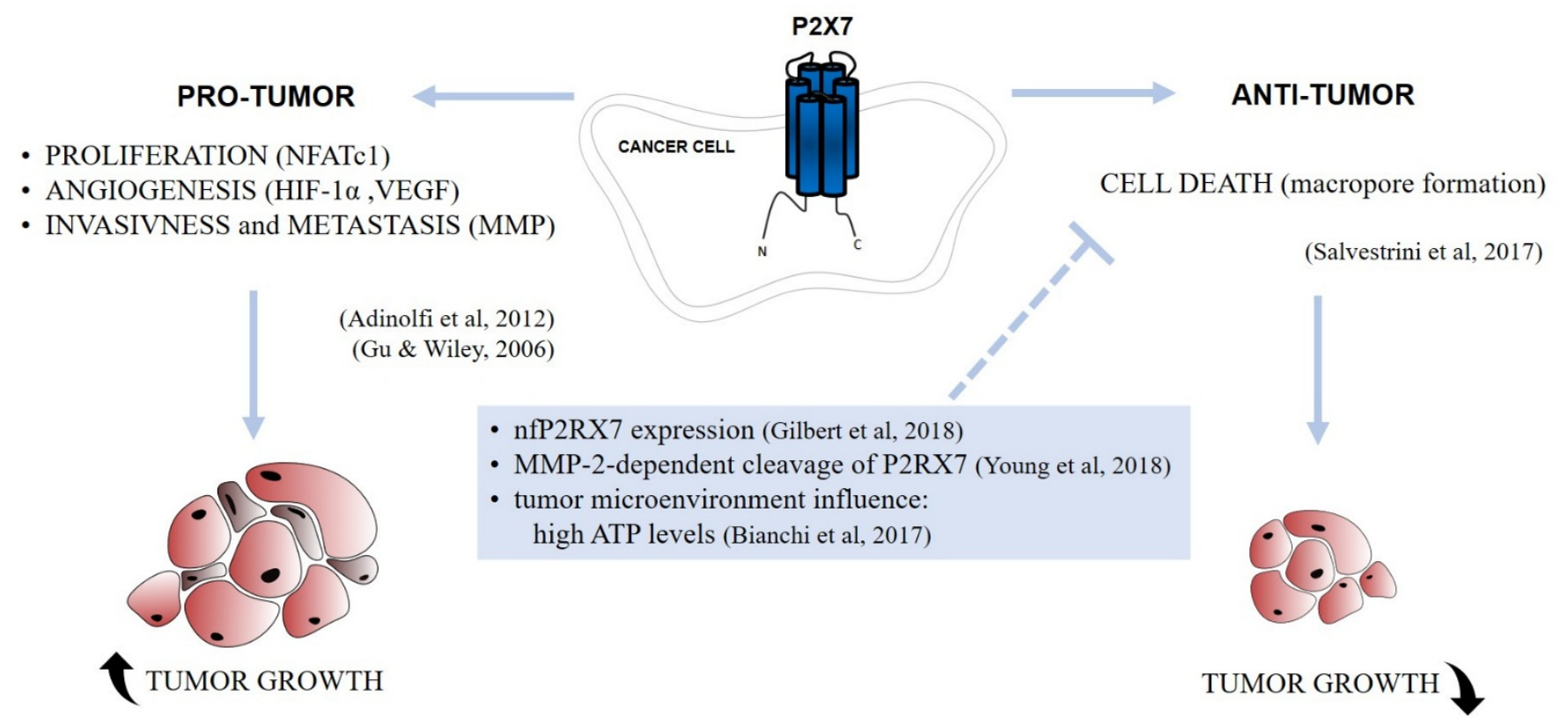

Figure 1. Schematic representation of $P 2 X 7 R$ dual-role in cancer cells: pro- and anti-tumor effects are shown. Its activation can enhance tumor growth by promoting proliferation, angiogenesis, invasiveness and metastasis. On the contrary, it could lead to cancer cell death, reducing tumor growth, through macropore formation. This is counteracted by three main factors: nfP $2 X 7 R$ preferential expression, the cleavage of P2X7R by MMP-2 and by the possible onset of a resistance towards high ATP levels. 
Table 1. Patents Regarding $P 2 X 7 R$ in the Treatment of Cancer

\begin{tabular}{|c|c|c|}
\hline Title and Authors & Publication Number & P2X7R Involvment \\
\hline $\begin{array}{l}\text { New tumor marker for the } \\
\text { rhabdomyosarcoma } \\
\text { (Gesche } \text { et al, 2018) }\end{array}$ & US20180256743 & $\begin{array}{l}\text { P2X7R splicing variant is } \\
\text { expressed on RMS cell surface }\end{array}$ \\
\hline $\begin{array}{l}\text { Methods and Compositions to } \\
\text { Inhibit } \mathrm{P} 2 \mathrm{x} 7 \text { Receptor Expression } \\
\text { (Jimenez } \text { et al, 2011) }\end{array}$ & EP2287301 & $\begin{array}{c}\text { RNAi technology to } \\
\text { downregulate P2X7R expression } \\
\text { on cancer cells }\end{array}$ \\
\hline $\begin{array}{l}\text { In vitro method for modifying the } \\
\text { depletion profile of treg cells present } \\
\text { in a total splenocyte population of a } \\
\text { biological sample by means of the } \\
\text { isolation, culturing and exposure } \\
\text { thereof to an atp and polymixin b } \\
\text { medium } \\
\text { (Acuna et al, 2014) }\end{array}$ & US20140371159 & $\begin{array}{c}\text { Activation of P2X7R on Treg } \\
\text { cells enhances anti-tumor } \\
\text { responses }\end{array}$ \\
\hline $\begin{array}{l}\text { Novel p2x7 epitopes } \\
\text { (Gidley-Baird \& Barden, 2018) }\end{array}$ & US15910987 & $\begin{array}{c}\text { Treatment of cancer by antibodies } \\
\text { anti-P2X7R }\end{array}$ \\
\hline $\begin{array}{l}\text { Anti- p2x7 peptides and epitopes } \\
\text { (Barden \& Gidley-Baird, 2016) }\end{array}$ & EP2318438B1 & $\begin{array}{l}\text { Identification of novel epitope on } \\
\text { cancer-related nfP2X7R }\end{array}$ \\
\hline $\begin{array}{l}\text { Combination therapy } \\
\text { (Barden \& Gidley-Baird, 2018) }\end{array}$ & EP2726095B1 & $\begin{array}{c}\text { Humoral response against P2X7R } \\
\text { in individuals having cancer }\end{array}$ \\
\hline $\begin{array}{l}\text { P2X7 inhibition of epithelial } \\
\text { cancers and papillomas } \\
\text { (Gorodeski \& Fu, 2013) }\end{array}$ & EP2509605 & $\begin{array}{l}\text { Local activation of PX7R inhibits } \\
\text { development and progresion of } \\
\text { epidermal premalignant lesions }\end{array}$ \\
\hline $\begin{array}{l}\text { Methods for treatment of primary } \\
\text { cancer and cancer metastasis } \\
\text { (Jiang \& Zhou, 2015) }\end{array}$ & US20150297623 & $\begin{array}{l}\text { P2X7R agonists as a method for } \\
\text { the treatment of metastatic cancer }\end{array}$ \\
\hline
\end{tabular}




\section{ETHICS APPROVAL AND CONSENT TO}

\section{PARTICIPATE}

Not applicable

\section{HUMAN AND ANIMAL RIGHTS???}

No Animals/Humans were used for studies that are base of

this review.

\section{CONSENT FOR PUBLICATION}

Not applicable.

\section{CONFLICT OF INTEREST}

The authors declare that they have no conflict of inter-

ests.

\section{ACKNOWLEDGEMENTS}

The authors thank Federico Mussano for his support.

\section{REFERENCES}

[1] Giuliani AL, Sarti AC, Di Virgilio F. Extracellular nucleotides and nucleosides as signalling molecules. Immunol Lett. Epub ahead of print 12 November 2018. DOI: 10.1016/j.imlet.2018.11.006.

[2] Burnstock G. Purinergic signalling: Therapeutic developments. Front Pharmacol; 8. Epub ahead of print 2017. DOI: 10.3389/fphar.2017.00661.

[3] Burnstock G, Verkhratsky A. Evolutionary origins of the purinergic signalling system. Acta Physiol 2009; 195: 415-447.

[4] Burnstock G. Discovery of purinergic signalling, the initial resistance and current explosion of interest. $\mathrm{Br}$ $J$ Pharmacol 2012; 167: 238-255.

[5] Nishimura A, Sunggip C, Oda S, et al. Purinergic P2Y receptors: Molecular diversity and implications for treatment of cardiovascular diseases. Pharmacol Ther 2017; 180: 113-128.

[6] Burnstock G, Knight GE. The potential of P2X7 receptors as a therapeutic target, including inflammation and tumour progression. Purinergic Signal 2018; 14: 1-18.

[7] De Marchi E, Orioli E, Dal Ben D, et al. P2X7 Receptor as a Therapeutic Target. In: Advances in protein chemistry and structural biology. 2016, pp. 39-79.

[8] Di Virgilio F, Dal Ben D, Sarti AC, et al. The P2X7 Receptor in Infection and Inflammation. Immunity 2017; 47: 15-31.

[9] Mehta N, Kaur M, Singh M, et al. Purinergic receptor P2X7: A novel target for anti-inflammatory therapy.
Bioorganic Med Chem 2014; 22: 54-88.

[10] Burnstock G. P2X ion channel receptors and inflammation. Purinergic Signal 2016; 12: 59-67.

[11] Karasawa A, Michalski K, Mikhelzon P, et al. The P2X7 receptor forms a dye-permeable pore independent of its intracellular domain but dependent on membrane lipid composition. Elife; 6. Epub ahead of print 2017. DOI: 10.7554/eLife.31186.

Young CNJ, Sinadinos A, Lefebvre A, et al. A novel mechanism of autophagic cell death in dystrophic muscle regulated by $\mathrm{P} 2 \mathrm{RX} 7$ receptor large-pore formation and HSP90. Autophagy 2015; 11: 113-130.

[13] Young CNJ, Górecki DC. P2RX7 Purinoceptor as a Therapeutic Target-The Second Coming? Front Chem 2018; 6: 248.

[14] Di Virgilio F, Schmalzing G, Markwardt F. The Elusive P2X7 Macropore. Trends Cell Biol 2018; 28: 392-404.

[15] Hattori M, Gouaux E. Molecular mechanism of ATP binding and ion channel activation in $\mathrm{P} 2 \mathrm{X}$ receptors. Nature 2012; 485: 207-212.

[16] Pan H, Ni H, Zhang L, et al. P2RX7-V3 is a novel oncogene that promotes tumorigenesis in uveal melanoma. Tumor Biol 2016; 37: 13533-13543.

[17] Yang Y-C, Chang T-Y, Chen T-C, et al. Functional variant of the $\mathrm{P} 2 \mathrm{X} 7$ receptor gene is associated with human papillomavirus-16 positive cervical squamous cell carcinoma. Oncotarget 2016; 7: 82798-82803.

[18] Barden JA, Yuksel A, Pedersen J, et al. NonFunctional P2X7: A Novel and Ubiquitous Target in Human Cancer. J Clin Cell Immunol; 05. Epub ahead of print 2014. DOI: 10.4172/2155-9899.1000237.

[19] Gilbert S, Oliphant C, Hassan S, et al. ATP in the tumour microenvironment drives expression of nfP2X7, a key mediator of cancer cell survival. Oncogene 2018; 1.

[20] Feng YH, Li X, Wang L, et al. A Truncated P2X 7 Receptor Variant (P2X 7-j ) Endogenously Expressed in Cervical Cancer Cells Antagonizes the Full-length P2X 7 Receptor through Hetero-oligomerization. J Biol Chem 2006; 281: 17228-17237.

[21] Gidley-Baird A, Barden JA. Antibodies to nonfunctional P2X7 receptor. EP1961767B1 (2012).

[22] Barden JA, Sluyter R, Gu BJ, et al. Specific detection of non-functional human P2X7receptors in HEK293 cells and B-lymphocytes. FEBS Lett 2003; 538: 159 162.

[23] Hanahan D, Weinberg RA. Hallmarks of Cancer: The Next Generation. Cell 2011; 144: 646-674.

[24] Dewhirst MW, Lee C-T, Ashcraft KA. The future of biology in driving the field of hyperthermia. Int $J$ Hyperthermia 2016; 32: 4-13.

[25] Acuña-Castillo C, Coddou C, Bull P, et al. Differential role of extracellular histidines in copper, zinc, magnesium and proton modulation of the P2X7 purinergic receptor. J Neurochem 2006; 101: 17-26.

[26] Tafani M, Di Vito M, Frati A, et al. Pro-inflammatory gene expression in solid glioblastoma microenvironment and in hypoxic stem cells from 
human glioblastoma. J Neuroinflammation; 8. Epub ahead of print 2011. DOI: 10.1186/1742-2094-8-32.

[27] Azimi I, Beilby H, Davis FM, et al. Altered purinergic receptor-Ca2+ signaling associated with hypoxiainduced epithelial-mesenchymal transition in breast cancer cells. Mol Oncol 2016; 10: 166-178.

[28] Burnstock G. The therapeutic potential of purinergic signalling. Biochem Pharmacol 2018; 151: 157-165.

[29] Roger S, Pelegrin P. P2X7 receptor antagonism in the treatment of cancers. Expert Opin Investig Drugs 2011; 20: 875-880.

[30] Hilpert K, Hubler F, Renneberg D, et al. Heterocyclic amide derivatives as p2x7 receptor antagonists. US9388198B2 (2016).

[31] Gunosewoyo H, Kassiou M. P2X purinergic receptor ligands: recently patented compounds. Expert Opin Ther Pat 2010; 20: 625-46.

[32] Cieślak M, Wojtczak A. Role of purinergic receptors in the Alzheimer's disease. Purinergic Signal 2018; $1-14$.

[33] Tang Y, Yin H, Liu J, et al. P2X receptors and acupuncture analgesia. Brain Res Bull. Epub ahead of print $17 \quad$ November 2018. DOI: 10.1016/j.brainresbull.2018.10.015.

[34] Sesto A, Roman JP, Jimenez AI, et al. Methods and Compositions to Inhibit P2x7 Receptor Expression. EP2287301A3 (2011).

[35] Savio LEB, de Andrade Mello P, da Silva CG, et al. The P2X7 Receptor in Inflammatory Diseases: Angel or Demon? Front Pharmacol 2018; 9: 52.

[36] Abderrazak A, Syrovets T, Couchie D, et al. NLRP3 inflammasome: From a danger signal sensor to a regulatory node of oxidative stress and inflammatory diseases. Redox Biol 2015; 4: 296-307.

[37] Acuna C, Capelli C, Coddou C, et al. In vitro method for modifying the depletion profile of treg cells present in a total splenocyte population of a biological sample by means of the isolation, culturing and exposure thereof to an atp and polymixin $b$ medium. US20140371159A1 (2014).

[38] Franses JW, Baker AB, Chitalia VC, et al. Stromal endothelial cells directly influence cancer progression. Sci Transl Med 2011; 3: 66ra5.

[39] Anari F, Ramamurthy C, Zibelman M. Impact of tumor microenvironment composition on therapeutic responses and clinical outcomes in cancer. Futur Oncol 2018; 14: 1409-1421.

[40] Zuccolo E, Laforenza U, Ferulli F, et al. Stim and Orai mediate constitutive $\mathrm{Ca} 2+$ entry and control endoplasmic reticulum $\mathrm{Ca} 2+$ refilling in primary cultures of colorectal carcinoma cells. Oncotarget 2018; 9: 31098-31119.

[41] Iamshanova O, Fiorio Pla A, Prevarskaya N. Molecular mechanisms of tumour invasion: regulation by calcium signals. $J$ Physiol 2017; 595: 3063-3075.

[42] Cui C, Merritt R, Fu L, et al. Targeting calcium signaling in cancer therapy. Acta Pharm Sin B 2017; 7: 3-17.
[43] Moccia F. Endothelial Ca2+signaling and the resistance to anticancer treatments: Partners in crime. International Journal of Molecular Sciences; 19. Epub ahead of print 2018. DOI: 10.3390/ijms 19010217.

[44] Lodola F, Laforenza U, Cattaneo F, et al. VEGFinduced intracellular $\mathrm{Ca} 2+$ oscillations are downregulated and do not stimulate angiogenesis in breast cancer-derived endothelial colony forming cells. Oncotarget 2017; 8: 95223-95246.

[45] Poletto V, Dragoni S, Lim D, et al. Endoplasmic Reticulum $\mathrm{Ca}^{2+}$ Handling and Apoptotic Resistance in Tumor-Derived Endothelial Colony Forming Cells. J Cell Biochem 2016; 117: 2260-2271.

[46] Petrillo S, Chiabrando D, Genova T, et al. Heme accumulation in endothelial cells impairs angiogenesis by triggering paraptosis. Cell Death Differ 2018; 25: 573-588.

[47] Fiorio Pla A, Genova T, Pupo E, et al. Multiple Roles of Protein Kinase A in Arachidonic Acid-Mediated $\mathrm{Ca} 2+$ Entry and Tumor-Derived Human Endothelial Cell Migration. Mol Cancer Res 2010; 8: 1466-1476.

[48] Genova T, Grolez GP, Camillo C, et al. TRPM8 inhibits endothelial cell migration via a non-channel function by trapping the small GTPase Rap1. J Cell Biol 2017; 216: 2107-2130.

[49] Munaron L, Genova T, Avanzato D, et al. Targeting calcium channels to block tumor vascularization. Recent Pat Anticancer Drug Discov 2013; 8: 27-37.

[50] Fiorio Pla A, Brossa A, Bernardini M, et al. Differential sensitivity of prostate tumor derived endothelial cells to sorafenib and sunitinib. $B M C$ Cancer 2014; 14: 939.

[51] Petrillo S, Tolosano E, Munaron L, et al. Targeting Metabolism to Counteract Tumor Angiogenesis: A Review of Patent Literature. Recent Pat Anticancer Drug Discov 2018; 13: 422-427.

[52] Fang J, Chen X, Wang S, et al. The expression of P2X 7 receptors in EPCs and their potential role in the targeting of EPCs to brain gliomas. Cancer Biol Ther 2015; 16: 498-510.

[53] Moccia F, Zuccolo E, Poletto V, et al. Endothelial progenitor cells support tumour growth and metastatisation: implications for the resistance to antiangiogenic therapy. Tumor Biol 2015; 36: 66036614.

[54] Zuccolo E, Di Buduo C, Lodola F, et al. Stromal CellDerived Factor-1 $\alpha$ Promotes Endothelial ColonyForming Cell Migration Through the $\mathrm{Ca} \mathrm{2+}$ Dependent Activation of the Extracellular SignalRegulated Kinase 1/2 and Phosphoinositide 3Kinase/AKT Pathways. Stem Cells Dev 2018; 27: 23 34.

[55] Amoroso F, Falzoni S, Adinolfi E, et al. The P2X7 receptor is a key modulator of aerobic glycolysis. Cell Death Dis 2012; 3: e370-e370.

[56] Adinolfi E, Raffaghello L, Giuliani AL, et al. Expression of $\mathrm{P} 2 \mathrm{X} 7$ receptor increases in vivo tumor growth. Cancer Res 2012; 72: 2957-69. 
[57] Amoroso F, Capece M, Rotondo A, et al. The P2X7 receptor is a key modulator of the PI3K/GSK3ß/VEGF signaling network: Evidence in experimental neuroblastoma. Oncogene 2015; 34: 5240-5251.

[58] Gu BJ, Wiley JS. Rapid ATP-induced release of matrix metalloproteinase 9 is mediated by the P2X7 receptor. Blood 2006; 107: 4946-4953.

[59] Basilico N, Magnetto C, D'Alessandro S, et al. Dextran-shelled oxygen-loaded nanodroplets reestablish a normoxia-like pro-angiogenic phenotype and behavior in hypoxic human dermal microvascular endothelium. Toxicol Appl Pharmacol 2015; 288: 330-338.

[60] Ji Z, Xie Y, Guan Y, et al. Involvement of P2X7 Receptor in Proliferation and Migration of Human Glioma Cells. Biomed Res Int 2018; 2018: 8591397.

[61] Adinolfi E, Melchiorri L, Falzoni S, et al. P2X7 receptor expression in evolutive and indolent forms of chronic B lymphocytic leukemia. Blood 2002; 99: 706-708.

[62] Gómez-Villafuertes R, García-Huerta P, DíazHernández JI, et al. PI3K/Akt signaling pathway triggers $\mathrm{P} 2 \mathrm{X} 7$ receptor expression as a pro-survival factor of neuroblastoma cells under limiting growth conditions. Sci Rep 2016; 5: 18417.

[63] Amoroso F, Salaro E, Falzoni S, et al. P2X7 targeting inhibits growth of human mesothelioma. Oncotarget 2016; 7: 49664-49676.

[64] Santos AA, Cappellari AR, de Marchi FO, et al. Potential role of P2X7R in esophageal squamous cell carcinoma proliferation. Purinergic Signal 2017; 13: 279-292.

[65] Giannuzzo A, Saccomano M, Napp J, et al. Targeting of the $\mathrm{P} 2 \mathrm{X} 7$ receptor in pancreatic cancer and stellate cells. Int J Cancer 2016; 139: 2540-2552.

[66] Slater M, Danieletto S, Pooley M, et al. Differentiation between Cancerous and Normal Hyperplastic Lobules in Breast Lesions. Breast Cancer Res Treat 2004; 83: 1-10.

[67] Greig AVH, Burnstock G, Linge C, et al. Expression of Purinergic Receptors in Non-melanoma Skin Cancers and Their Functional Roles in A431 Cells. $J$ Invest Dermatol 2003; 121: 315-327.

[68] Adinolfi E, Callegari MG, Ferrari D, et al. Basal activation of the $\mathrm{P} 2 \mathrm{X} 7 \mathrm{ATP}$ receptor elevates mitochondrial calcium and potential, increases cellular ATP levels, and promotes serum-independent growth. Mol Biol Cell 2005; 16: 3260-72.

[69] Gesche J, Armeanu-Ebinger S, Seitz G, et al. New tumor marker for the rhabdomyosarcoma. US20180256743A1 (2018).

[70] Di Virgilio F, Adinolfi E. Extracellular purines, purinergic receptors and tumor growth. Oncogene 2017; 36: 293-303.

[71] Vázquez-Cuevas FG, Martínez-Ramírez AS, RoblesMartínez L, et al. Paracrine Stimulation of P2X7 Receptor by ATP Activates a Proliferative Pathway in Ovarian Carcinoma Cells. J Cell Biochem 2014; 115 :
1955-1966.

[72] Gidley-Baird A, Barden. Novel p2x7 epitopes. US15910987 (2018).

[73] Barden JA, Gidley-Baird A. Anti- p2x7 peptides and epitopes. EP2318438B1 (2016).

[74] Gilbert SM, Gidley Baird A, Glazer S, et al. A phase I clinical trial demonstrates that $\mathrm{nfP}_{2} \mathrm{X}_{7}$-targeted antibodies provide a novel, safe and tolerable topical therapy for basal cell carcinoma. Br J Dermatol 2017; 177: 117-124.

[75] Barden JA, Gidley-Baird A. Combination therapy. EP2726095B1 (2018).

[76] Avanzato D, Genova T, Fiorio Pla A, et al. Activation of P2X7 and P2Y11 purinergic receptors inhibits migration and normalizes tumor-derived endothelial cells via cAMP signaling. Sci Rep 2016; 6: 32602.

[77] Bianchi G, Vuerich M, Pellegatti P, et al. ATP/P2X7 axis modulates myeloid-derived suppressor cell functions in neuroblastoma microenvironment. Cell Death Dis 2017; 5: e1135-e1135.

[78] Young CNJ, Chira N, Róg J, et al. Sustained activation of P2X7 induces MMP-2-evoked cleavage and functional purinoceptor inhibition. $\mathrm{J} \mathrm{Mol} \mathrm{Cell}$ Biol 2018; 10: 229-242.

[79] Gorodeski G, Fu W. P2X7: inhibition of epithelial cancers and papillomas. EP2509605A4 (2013).

[80] Jiang JX, Zhou JZ. Methods for treatment of primary cancer and cancer metastasis. US20150297623A1 (2015).

[81] Morrone FB, Gehring MP, Nicoletti NF. Calcium Channels and Associated Receptors in Malignant Brain Tumor Therapy. Mol Pharmacol 2016; 90: 403-9.

[82] Prevarskaya N, Skryma R, Shuba Y. Ion Channels in Cancer: Are Cancer Hallmarks Oncochannelopathies? Physiol Rev 2018; 98: 559621.

[83] Prevarskaya N, Skryma R, Shuba Y. Calcium in tumour metastasis: new roles for known actors. Nat Rev Cancer 2011; 11: 609-618.

[84] Rao VR, Perez-Neut M, Kaja S, et al. Voltage-gated ion channels in cancer cell proliferation. Cancers (Basel) 2015; 7: 849-75.

[85] Harder BG, Blomquist MR, Wang J, et al. Developments in Blood-Brain Barrier Penetrance and Drug Repurposing for Improved Treatment of Glioblastoma. Front Oncol 2018; 8: 462.

[86] Territo PR, Meyer JA, Peters JS, et al. Characterization of 11C-GSK1482160 for Targeting the P2X7 Receptor as a Biomarker for Neuroinflammation. J Nucl Med 2017; 58: 458-465.

[87] Beamer E, Gölöncsér F, Horváth G, et al. Purinergic mechanisms in neuroinflammation: An update from molecules to behavior. Neuropharmacology 2016; 104: 94-104.

[88] Chrovian CC, Rech JC, Bhattacharya A, et al. P2X7 Antagonists as Potential Therapeutic Agents for the Treatment of CNS Disorders. Prog Med Chem 2014; 53: 65-100. 
[89] Friedle SA, Curet MA, Watters JJ. Recent patents on novel P2X(7) receptor antagonists and their potential for reducing central nervous system inflammation. Recent Pat CNS Drug Discov 2010; 5: 35-45.

[90] Schain M, Kreisl WC. Neuroinflammation in Neurodegenerative Disorders-a Review. Curr Neurol Neurosci Rep 2017; 17: 25.

[91] Wang X-H, Xie X, Luo X-G, et al. Inhibiting purinergic $\mathrm{P} 2 \mathrm{X} 7$ receptors with the antagonist brilliant blue $\mathrm{G}$ is neuroprotective in an intranigral lipopolysaccharide animal model of Parkinson's disease. Mol Med Rep 2017; 15: 768-776.

[92] Domercq M, Zabala A, Matute C. Purinergic receptors in multiple sclerosis pathogenesis. Brain Res Bull 2018; 0-1.

[93] Cieślak M, Roszek K, Wujak M. Purinergic implication in amyotrophic lateral sclerosis-from pathological mechanisms to therapeutic perspectives. Purinergic Signalling, 14 November 2018. Epub ahead of print 14 November 2018. DOI: 10.1007/s1 1302-018-9633-4.

[94] Aquilino MS, Whyte-Fagundes P, Zoidl G, et al. Pannexin-1 channels in epilepsy. Neurosci Lett. Epub ahead of print 5 September 2017. DOI: 10.1016/j.neulet.2017.09.004.

[95] Pevarello P, Lohmer S. Substituted thiazole or oxazole as $\mathrm{P} 2 \mathrm{X} 7$ receptor antagonists. US9718812B2
(2017).

[96] Dean DK, Walter DS. Thiadiazolidinedioxide $p 2 x 7$ receptor antagonists. WO2011054947A1 (2011).

[97] Letavic MA, Rech JC, Wall JL. P2x7 modulators. EP3191492A (2017).

[98] Andres Gil JI, Letavic MA, Rech JC, et al. P2x7 modulating n-acyl-triazolopyrazines. US20180118749A1 (2018).

[99] Park J-H, Kim Y-C. P2X7 receptor antagonists: a patent review (2010-2015). Expert Opin Ther Pat 2017; 27: 257-267.

[100] Abdel-Magid AF. Promising Therapeutic Potential of P2X7 Modulators. ACS Med Chem Lett 2016; 7: 34850.

[101] Adinolfi E, Capece M, Franceschini A, et al. Accelerated tumor progression in mice lacking the ATP receptor P2X7. Cancer Res 2015; 75: 635-44.

[102] Salvestrini V, Orecchioni S, Talarico G, et al. Extracellular ATP induces apoptosis through P2X7R activation in acute myeloid leukemia cells but not in normal hematopoietic stem cells. Oncotarget 2016; 8: 5895-5908. 